Databases, Revenues, \& Repertory: The French Stage Online, 16801793 - Databases, Revenues, \& Repertory: The French Stage Online, 1680-1793

\title{
Financial Difficulties and Business Strategies at the Comédie-Française During the Seven Years War
}

Thomas M. Luckett

Published on: Oct 07, 2020

DOI: 10.21428/671d579e.c3624c72

License: Creative Commons Attribution 4.0 International License (CC-BY 4.0). 
Four decades later Mlle Clairon, one of France's most celebrated actresses, would recall in her memoirs the financial challenges that the troupe of the ComédieFrançaise had experienced in the late 1750s. "Nous étions pauvres, hors d'état d'attendre ce qui pouvait nous être dû. Les semainiers allaient, toutes les semaines, chez M. de Boulogne [sic], alors contrôleur-général, solliciter le paiement de la pension du roi, et n'obtenaient rien." At last Clairon herself went with seven of her comrades to implore Boullongne. “Le ministre m’apperçut, éloigna la foule qui l'entourait, et vint me demander ce qui m’amenait. Ma réponse fut : Le désespoir, monseigneur, où nous réduisent nos besoins et vos refus." Jean de Boullongne, comte de Nogent, served as controller-general for less than eighteen months, from 25 August 1757 to 4 March 1759 , just as the accounts of the Comédie-Française were sliding into the red. Though Clairon's memoirs are often unreliable, it is telling that she would highlight this moment as a time of particular hardship. $\underline{1}$

The period of the late 1750s presents a unique opportunity to understand the financial administration of the Comédie-Française. $\underline{2}$ While detailed registers of the theater's receipts have survived from 1680 through 1793 (with the exception of the lost register for 1739-40), for five fiscal years from April 1755 to March 1760 the accountants of the Comédie-Française also assembled detailed monthly accounts of the theater's expenses. $\underline{3}$ These expense registers permit us to generate particularly fine-grained data series of the theater's costs, profits and losses, as well as the dividends it paid to its actors and actresses. $\stackrel{4}{*}$ For the subsequent period, starting fiscal year 1760-61, the accountants abandoned monthly accounts in favor of annual expense accounts that, though less detailed, are nevertheless crucial for understanding how the theater recovered after 1760. $\underline{5}$ Additionally, in consequence of a council decree of 18 June 1757, on 9 June 1758 the troupe approved a complete revision of their bylaws in the form of new articles of incorporation that, together with the minutes of their weekly business meetings, offer a detailed description of the theater's internal administrative procedures. $\underline{6}$

The period of the late 1750 s is also of interest because it corresponds to the height of the Seven Years War between Britain and France, which had begun unofficially in 1754, and officially with the British declaration of war in May 1756. In eighteenthcentury France, major wars tended to be times of economic downturn. The cost of warfare disrupted French capital markets and pushed the monarchy's archaic fiscal system to the brink of bankruptcy, as occurred in November 1759 when Etienne de 
Silhouette, Boullongne's successor in the office of controller-general, issued a major default on the king's debts. Britain's superior navy seized French merchant vessels and closed sea lanes to French shipping, with deleterious effect on French foreign and colonial trade. As their incomes declined, Parisians might be expected to limit spending on luxuries, including theater tickets.

Between 1757-58 and 1761-62, after subtracting dividends paid to the actors and actresses, the Comédie-Française lost money every fiscal year. The shortfall resulted from increased expenses as much as from reduced revenues. The evidence suggests that in an effort to attract audiences the troupe experimented with new strategies for selecting plays for performance, but their recovery starting in about 1761 ultimately depended more on controlling costs than on improving ticket sales. The crisis forced the troupe to make a variety of changes in their business operations, ranging from short-term expedients to long-term reforms. By the end of the war their business was more professionally administered than previously, and its financial stability restored.

\section{The internal administration of the Comédie-Française in the 1750s}

As a business the Comédie-Française operated on a profit-sharing basis, distributing monthly profits as dividends (parts) to the actors and actresses themselves. Historian Lauren R. Clay has shown that, though such a business model had been the norm for French theaters in the sixteenth and seventeenth centuries, by the eighteenth century it was more unusual. The capital of the Comédie-Française was constituted as twentythree shares (which like the dividends were known as parts), but these were not publicly traded. Rather, as new actors and actresses joined the troupe, each one purchased either a share or some fraction of a share from a retiring actor or actress. For one full share the new member paid the outgoing member a fixed price of 8,730 L $15 \mathrm{~s} 5 \mathrm{~d}$, plus an additional payment of 4,400 L that was not technically considered part of the purchase price, for a total of 13,130 L 15 s $5 \mathrm{~d}$. A young performer, of course, would not have such investment capital ready to hand. Instead, the theater itself would advance the cost of the share out of its cash reserve as a zero-interest loan that the new member would then reimburse in installments of 1,000 L per year, deducted from his or her compensation. $\underline{7}$

The administration of the Comédie-Française was so remarkably democratic that one observer described it as a "republic." All important business decisions were made by 
the weekly assembly of the troupe, which met every Monday morning at eleven. For their attendance actors and actresses were each paid an honorarium (jeton d'assemblée) that, originally set at three livres per session, was increased to six livres starting 21 November 1757. Since no member of the troupe could own more than one full share, while several owned only partial shares, the number of share-holding troupe members eligible to attend these sessions fluctuated between about twenty-six and twenty-eight. All received equal honoraria, and cast equal votes, regardless of their sex or the size of their shares. Sessions were chaired by the semainier, an executive position that rotated week-by-week among all the male members of the troupe, with the assistance of the second and third semainiers, who would take their turns as semainier over the following two weeks. The other actors and actresses sat around the table by order of seniority. Extraordinary meetings were also convened when the troupe had to consider a new play for inclusion in the repertory, and for these meetings each actor or actress received an honorarium (jeton de lecture) of three livres. As late as the 1750s, votes on new plays were also cast with beans-black for "decline," white for "accept," and a marbled bean for "accept with revisions" - but by 1769 this system would be replaced by one in which each participant prepared a written decision. $\underline{8}$

Beyond these honoraria for their attendance of business meetings, troupe members earned compensation in a variety of forms, some of which show up clearly in the expense registers, while others are only poorly documented. For each day they performed on stage in Paris, actors and actresses received wages known by the odd name of "fires" (feux), since they were ostensibly meant to fund the performers' wax candles. 9 Originally set at one livre per performance, regardless of the importance of the performer's role, the "fires" were increased to two livres per performance starting December 1757. During the high season the actors would also travel several times per month to Versailles to perform for the king and his entourage. Though the ComédieFrançaise itself received no payment for these command performances, the king paid each of the participating actors and actresses a "fire" of six livres for the day, and the theater paid an indemnity (préciput), to those actors and actresses who were unable to participate. Until the late 1750s, each year the theater paid shareholding actors and actresses a New Year bonus (étrennes) of 300 L per share, and throughout the year it distributed in the same fashion another $100 \mathrm{~L}$ per share per month known as the établissement, which was rationalized as interest accruing on the funds they had invested in their shares. The king also provided the Comédie-Française with an annual royal pension of $12,000 \mathrm{~L}$ that was redistributed to the shareholders in proportion to 
the size of their shares. Actors and actresses could retire after twenty years of service, or in some cases fifteen, after which, in addition to reimbursement of the purchase cost of their share, the theater would pay them an annual pension of 1,000 L for life. $\underline{10}$

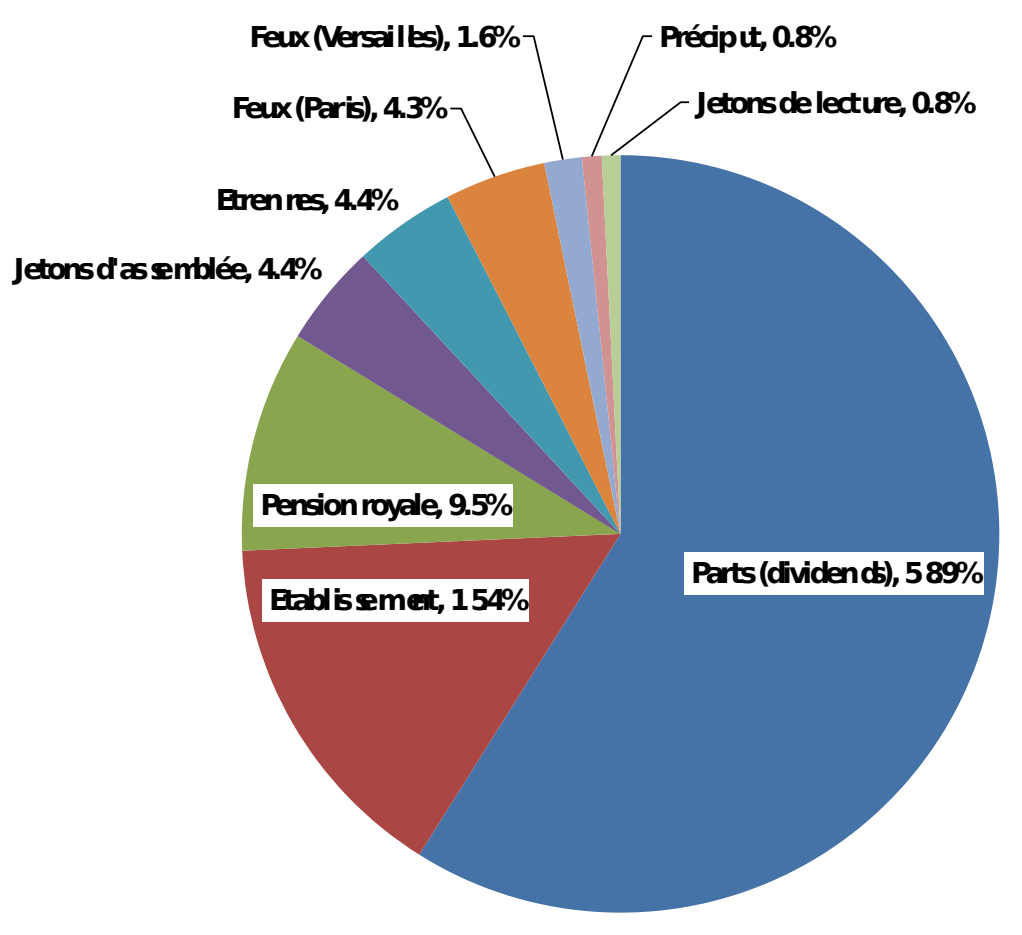

Figure 1. Composition of all compensation paid to actors \& actresses, fiscal years $1755-56$ to $1759-60$.

By far the largest item in the compensation package of actors and actresses, however, was the dividend, which depended primarily on the profits of the theater, and thus gave them a direct interest in the financial success of the company. Over the five fiscal years from 1755-56 to 1759-60, total dividends constituted nearly sixty percent of all compensation received by the actors and actresses. [Fig. 1] $\underline{11}$ Dividends varied greatly over the long run, and even showed considerable year-to-year volatility. [Fig. 2] Relatively high before 1720 , dividends bottomed out in the 1720 s to 1740 s, and then suddenly rose to a promising new peak of 4,746 L per share in fiscal year 1750-51. Over the following decade dividends were fairly stable at a level that, while high relative to previous decades, must have seemed low by comparison with the new norm of $1750-51 . \underline{12}$ 


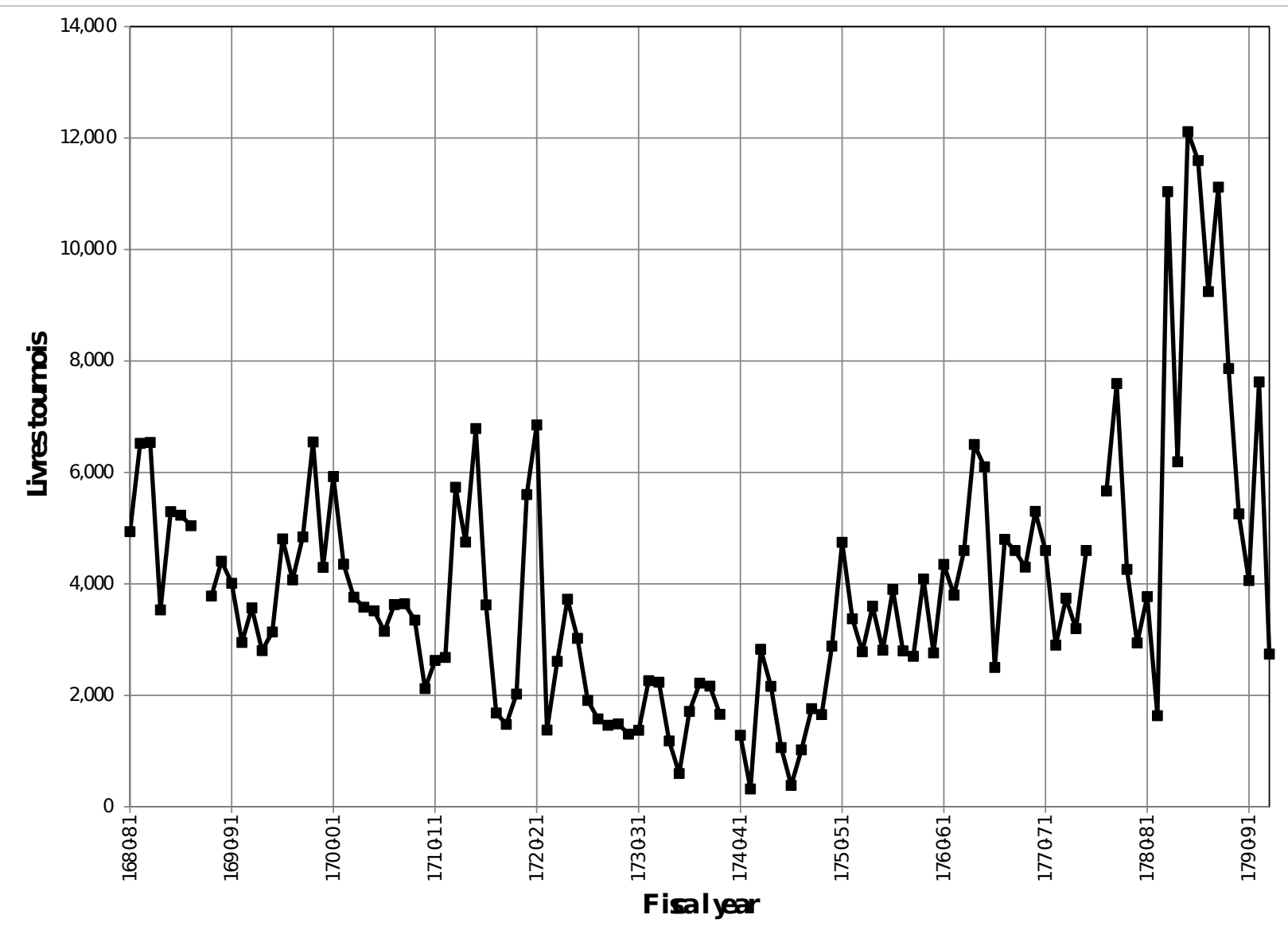

Figure 2. Annual dividends paid per share,
1680-81 to 1792-93.

In his Inquiry into the Nature and Causes of the Wealth of Nations (1776), Adam Smith observed that, due to the moral opprobrium under which they suffered in the eighteenth century, actors and actresses were paid at a far higher rate than comparable artists in more honorable arts. Actors in France were systematically marginalized through excommunication and disenfranchisement, as well as by the popular prejudice that Mlle Clairon in 1760 decried as "l'Infamie qu'on attache à mon état." $\underline{13}$ In addition to their labor and talent, stage performers had to be compensated for the "discredit" that they assumed, while prejudice also had the effect of discouraging entry to their profession, thus reducing competition. "It seems absurd at first sight," wrote Smith, "that we should despise their persons, and yet reward their talents with the most profuse liberality. While we do the one, however, we must necessarily do the other." The evidence of the Comédie-Française bears Smith out. While earnings varied somewhat among performers, in the 1750 s a member of the troupe who owned one full share could expect to receive roughly 5,000 L per year, taking all forms of income together, and by the 1780s the dividends alone rose well 
above 10,000 L. To cite a single point of contrast, at the outset of the Revolution the highest paid art professors at the Académie royale de peinture et de sculpture earned just 1,200 L per year. Among artists, stage performers constituted an economic elite, albeit an ostracized elite who, much like royal executioners, were formally excluded from public office or Christian communion. $\underline{14}$

\section{Financial distress and recovery during the Seven Years War}

Turning to the month-to-month data for the period 1755 to 1760 , we get a much clearer picture how dividends were administered. [Fig. 3] At the end of each month the accountants of the Comédie-Française would add up the month's total revenues and expenses, and then subtract to find the net surplus. At their weekly business meeting, the troupe would decide how much of this surplus to allocate to their own dividends. The theater's revenues were generally low in the spring and somewhat higher in the summer, peaking during autumn and winter, and the dividends typically followed the same seasonal pattern. Presumably the actors and actresses learned to save their earnings from each year's high season to tide them through the following low season. Occasionally, when the profits for the month were unusually high, rather than distribute the full amount to themselves as dividends, the troupe would prudently hold back some portion, as was notably the case in May and August 1755, January and February 1756, and February, March and August 1757. In this way they built the theater's cash reserve, which was managed during this period by retired actor François Baron, and thus appears in the expense registers as the caisse de M. Baron. $\underline{15}$ Dividends could not fall below zero, however, so in March 1758, when profits turned into losses, even though they received no dividends the troupe was forced to draw on their reserve to fund their other expenses. Similarly, in months in which profits were low, the troupe occasionally drew down the cash reserve to fund their dividends themselves, as occurred in July 1757 and September 1758. 


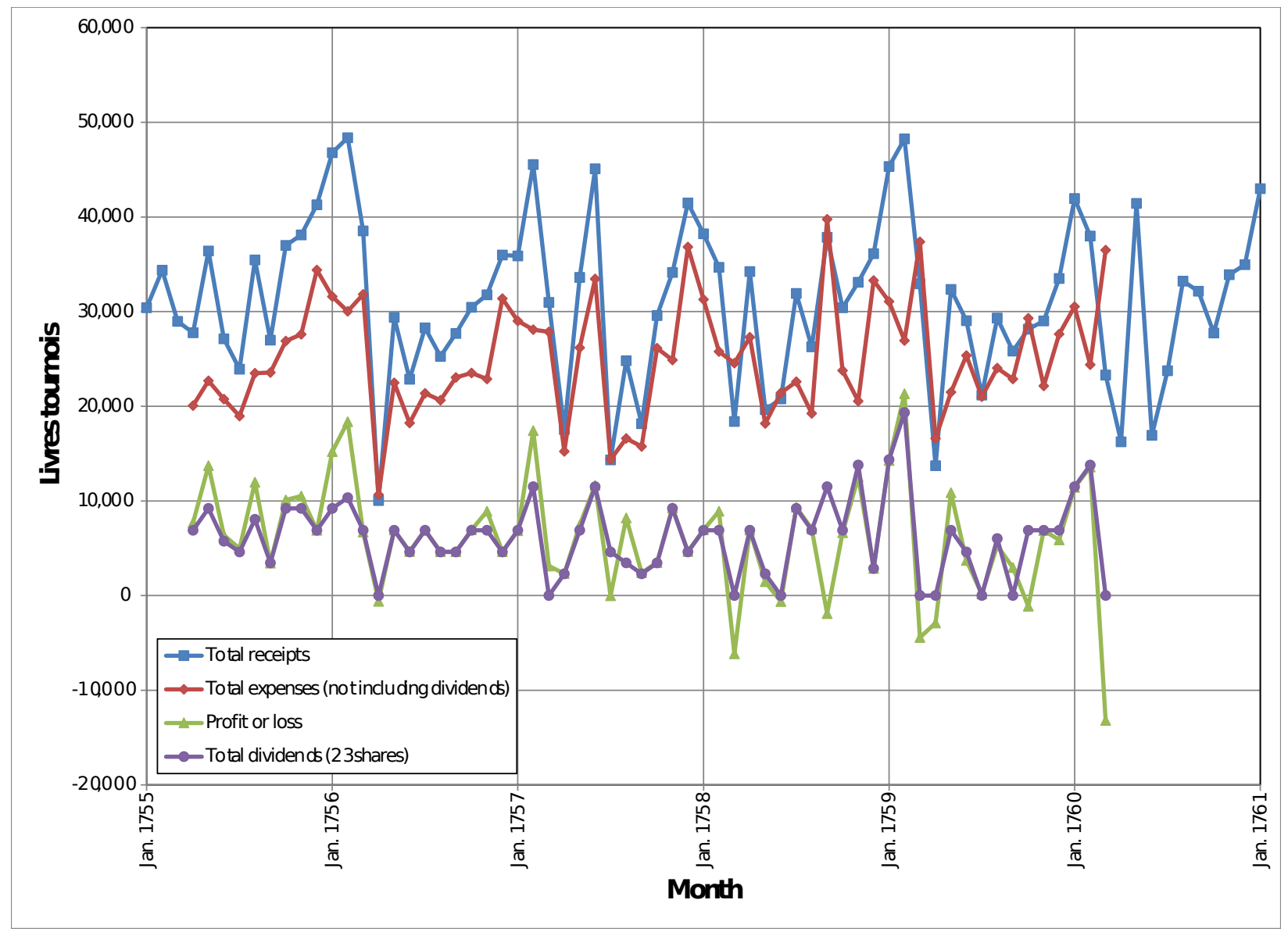

Figure 3. Monthly receipts, expenses, profits and dividends,
$1755-56$ to $1759-60$.

By the end of the 1750s, during fiscal years 1758-59 and 1759-60, the ComédieFrançaise found itself in serious financial difficulties, no longer earning profits at a sufficient level to fund the dividends of the actors and actresses. In 1757, in what amounted to a bailout, the king had paid down the troupe's long-term debt to the amount of 276,023 L, but this grant did little to improve the theater's day-to-day operations. $\frac{16}{16}$ In 1758-59 it appears that the troupe was able to muddle through by drawing down the surplus they had built in their cash reserve, but in 1759-60, as the cash reserve ran dry, their losses became more critical. The accountants of the Comédie-Française classified dividends as an expense, and each month they subtracted the total expenses, including dividends, from the total revenues to obtain the net change to the caisse de M. Baron. [Fig. 4] In fiscal year 1758-59 the troupe drew down the cash reserve by a total of 19,220 L, and in 1759-60 by an additional 18,633 L. No business can run this way for long. The registers of the ComédieFrançaise offer considerable evidence for the gravity of the situation. 


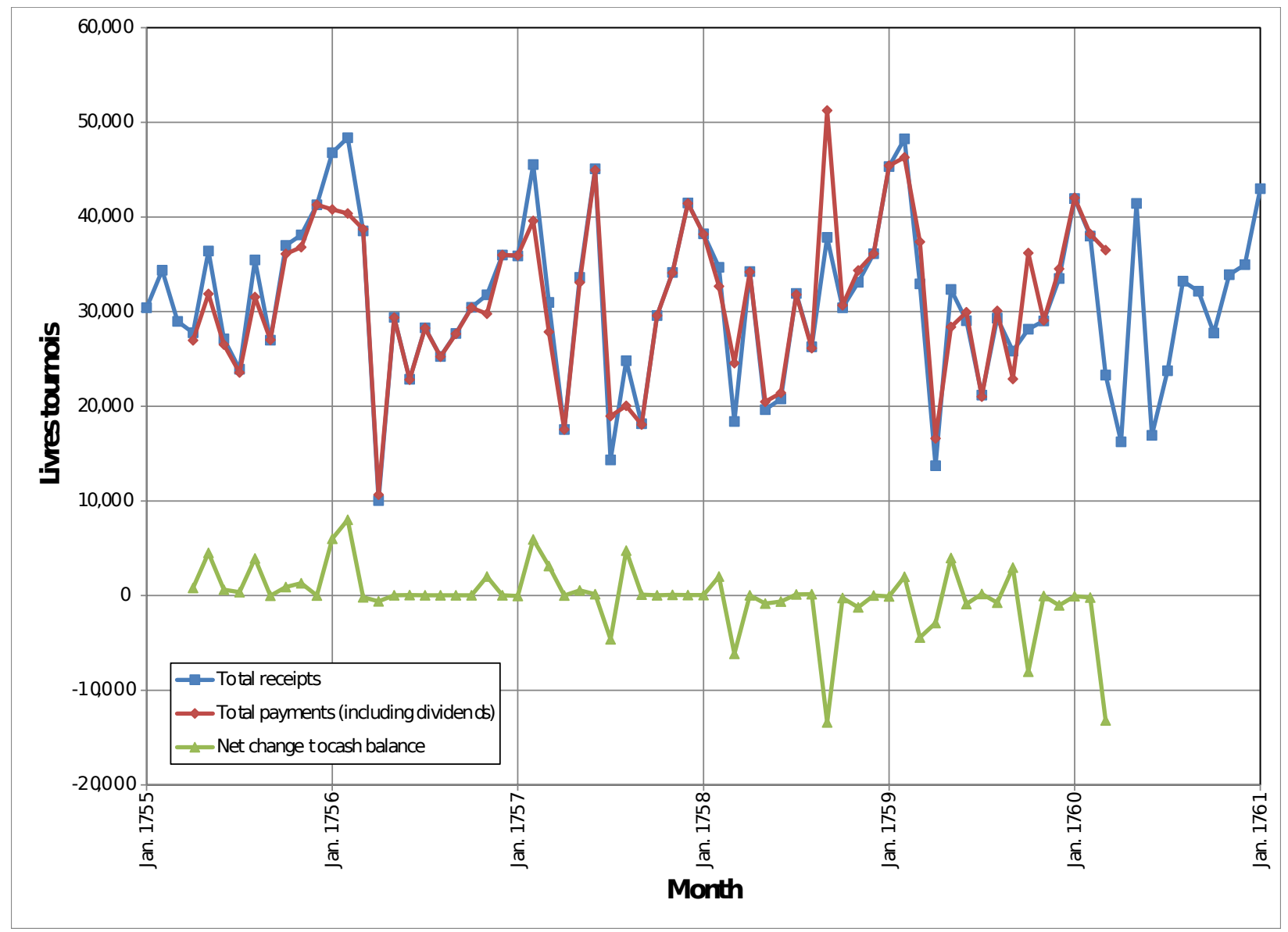

Figure 4. Monthly receipts, payments (including dividends) and net change to cash reserve, $1755-56$ to $1759-60$.

The minutes of the troupe's weekly business meetings show that by 1759 the theater was unable to finance its debts, and was forced on numerous occasions to renegotiate terms with its major creditors. In September 1759, when $\mathrm{M}^{\text {lle }}$ Melier sought payment for a promissory note that she had received from the theater in February in the amount of 3,150 L, the actor and current semainier Pierre-Louis du Bus Préville explained to her that "les circonstances du temps present jointes aux depenses excessives et extraord. ${ }^{\text {res }}$ qu'il a ete necessité de faire depuis louverture du theatre ne permettent pas quant a present le remboursem. ${ }^{\mathrm{t}}$ de lad somme." Melier offered to convert the obligation into a life annuity at ten percent per annum, payable quarterly, which the troupe approved and their notary, Nicolas de Savigny, formalized in a new contract. In November, Savigny himself pointed out that the Comédie-Française owed him 18,000 L for his past services, but he was willing to forgive 3,000 L, and the troupe found a way to transfer the remaining debt of $15,000 \mathrm{~L}$ to the office of the Menus Plaisirs du roi. At the same time they owed another 15,000 L to the Venet brothers, which the semainier Henri-Louis Lekain succeeded in renegotiating into a series of payments over the 
following two years. At the end of December the semainier Charles-Etienne Botot Dangeville persuaded another creditor, M. David, who like Melier had received in February a promissory note for 3,150 L payable in September, to accept just 1,200 L for the present, and the remainder in a series of installments over the following year. $\underline{17}$ The theater also lacked the funds to repurchase the shares of actors and actresses as they retired. In August 1760 the troupe did not have the 13,130 L 15 s 5 d needed to repurchase the share of actress Marie-Geneviève Dupré Grandval, who had retired the previous April. To come up with the amount they had to borrow 12,000 L at a term of six years from one Marie-Marguerite Perdu, a lender proposed by Grandval herself. In October 1760 the troupe had to sell off some of its financial assets in order to finance the repurchase of the share of actress Marie-Pauline Dumont Lavoy, who had retired eighteen months earlier. They decided to sell royal bonds (contrats sur les Etats de Bretagne) with a nominal value of $15,000 \mathrm{~L}$, aware that, due to the recent royal bankruptcy, they would receive considerably less than this amount in the current bond market, and they petitioned the Menus Plaisirs to cover the loss. The following year, in December 1761, the theater lacked the funds to repurchase the share of actress MarieHélène Lamotte or the half share of Marie-Jeanne Lemaignan Brillant, both of whom, like Lavoy, had retired in April 1759. At the same time a number of other large bills came due that the theater was equally unable to pay, including $12,000 \mathrm{~L}$ of the delayed payment to the Venet brothers that the troupe had already renegotiated in November 1759 , and a promissory note in the amount of 2,625 L to the widow Duchemin. In desperation the troupe decided to cede royal bonds with a nominal value of $120,000 \mathrm{~L}$ to the hospital administration in lieu of cash payment for taxes, and repurpose $32,471 \mathrm{~L} 2$ s 6 d of reserves already set aside for taxes to pay down their debts. $\underline{18}$ 


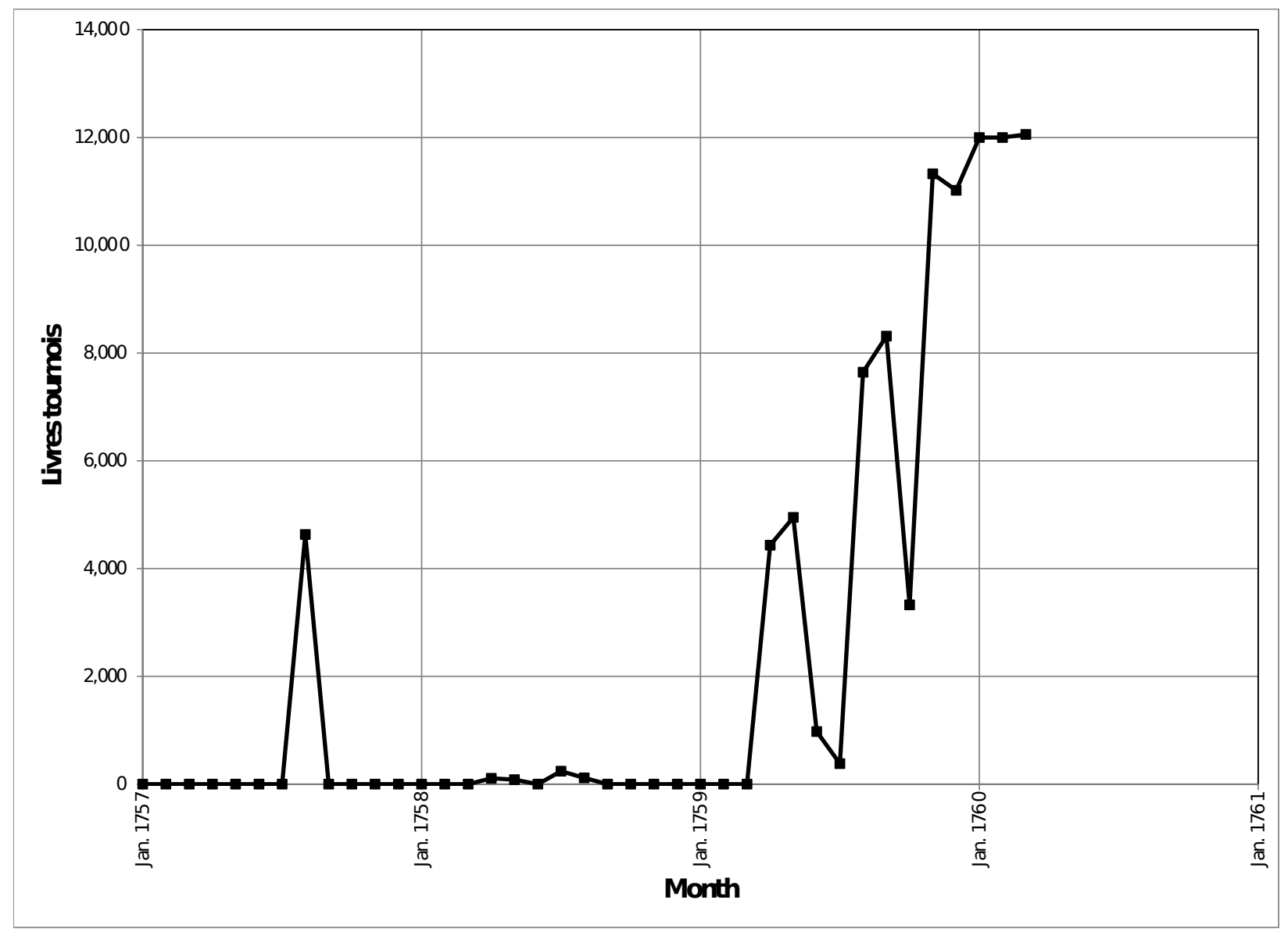

Figure 5. The troupe's outstanding "debt" to their own cash reserve,

$1757-58$ \& $1759-60$.

Another glimpse of the theater's financial difficulties is provided by a confusing accounting practice that the accountants of the Comédie-Française adopted during this period. [Fig. 5] Whenever the troupe's monthly expenses and dividends exceeded their revenues, the accountants treated the funds advanced from the cash reserve as a zero-interest loan with a term of just one month. The following month the troupe would repay the loan, at least on paper, by listing it as an expense in their expense account. If in fact they lacked the funds to repay the loan, they would then re-borrow the same money, and treat it once again as an expense the following month. The eventual repayments of these supposed loans, however, were never listed in their accounts as revenue. As their accumulated "debt" to themselves grew, it therefore appeared as a recurring monthly expense not matched by any revenue. To make sense of the theater's actual profits and losses, these artificial expenses have not been included in the graphs shown here, but they offer evidence of the financial hole into which the troupe had fallen. While this accumulated "debt" was minimal in fiscal year 1758-59, it rose rapidly the following year, reaching $12,000 \mathrm{~L}$ by the beginning of 1760 . The 
treatment of advances from the cash reserve as loans may also be related to a curious notation that appears in the monthly expense accounts for the last three months of 1759. During that period the actors and actresses received dividends of $300 \mathrm{~L}$ per share each month, which the accountants listed as "dividends by loan" (parts par emprunt). Unfortunately the registers do not explain what this phrase meant, but it probably referred to the fact that the dividends were largely advanced from the cash reserve.

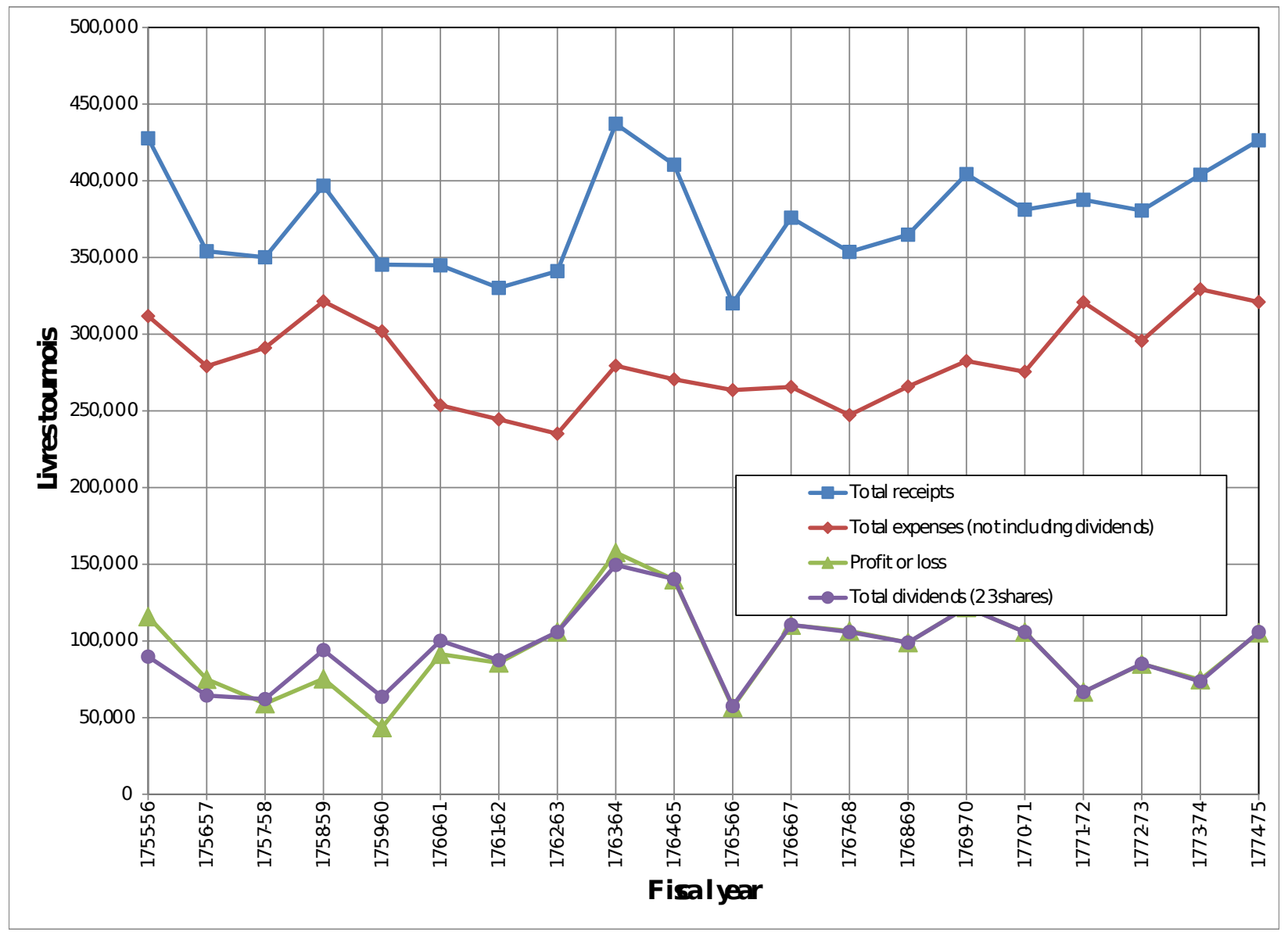

Figure 6. Annual receipts, expenses, profits and dividends,
1755-56 to 1774-75.

After March 1760 the accountants of the Comédie-Française apparently ceased to compile monthly expense accounts, but by then they had begun to prepare annual expense accounts, which have survived for the whole period from fiscal year 1759-60 to 1792-93. [Fig. 6] We can thus trace the fortunes of the Comédie-Française beyond the crisis of the late 1750s and follow its recovery in the early 1760 s, albeit without the

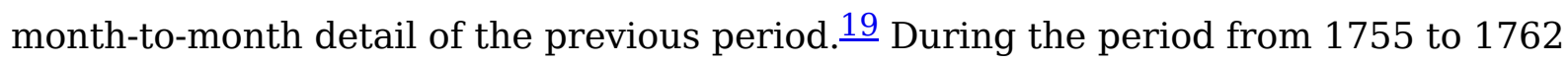
the sales of the Comédie-Française fell off considerably, while the expenses of the theater, many of which were fixed, did not decline as strongly. In fiscal year 1759-60 
the theater's fixed costs, which included such items as the wages of its employees and the pensions of its retirees as well as certain taxes, came to precisely 92,896 L 10 s per year, or thirty percent of total expenses (not including dividends). $\frac{20}{}$ As a result of declining revenues, profits thus also declined, appearing as a trough similar to that of the receipts. While the troupe moderated somewhat their demands for compensation, they nevertheless distributed dividends to themselves at a level not justified by their profits, thus substantially drawing down the cash reserve over three fiscal years, from 1758-59 through 1760-61. [Figs. 7 and 8]

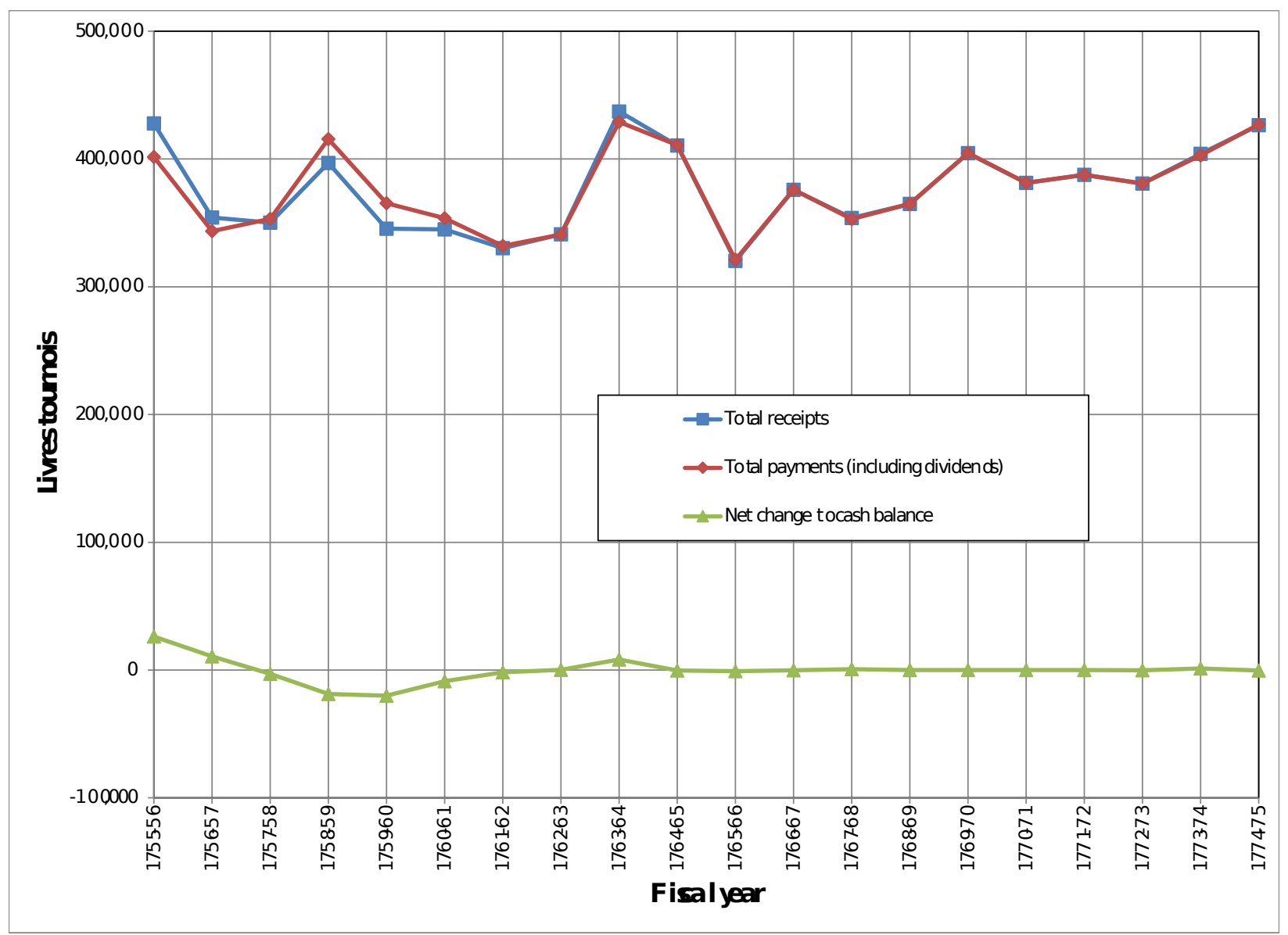

Figure 7. Annual receipts, payments (including dividends) and net change to cash reserve, $1755-56$ to $1774-75$. 


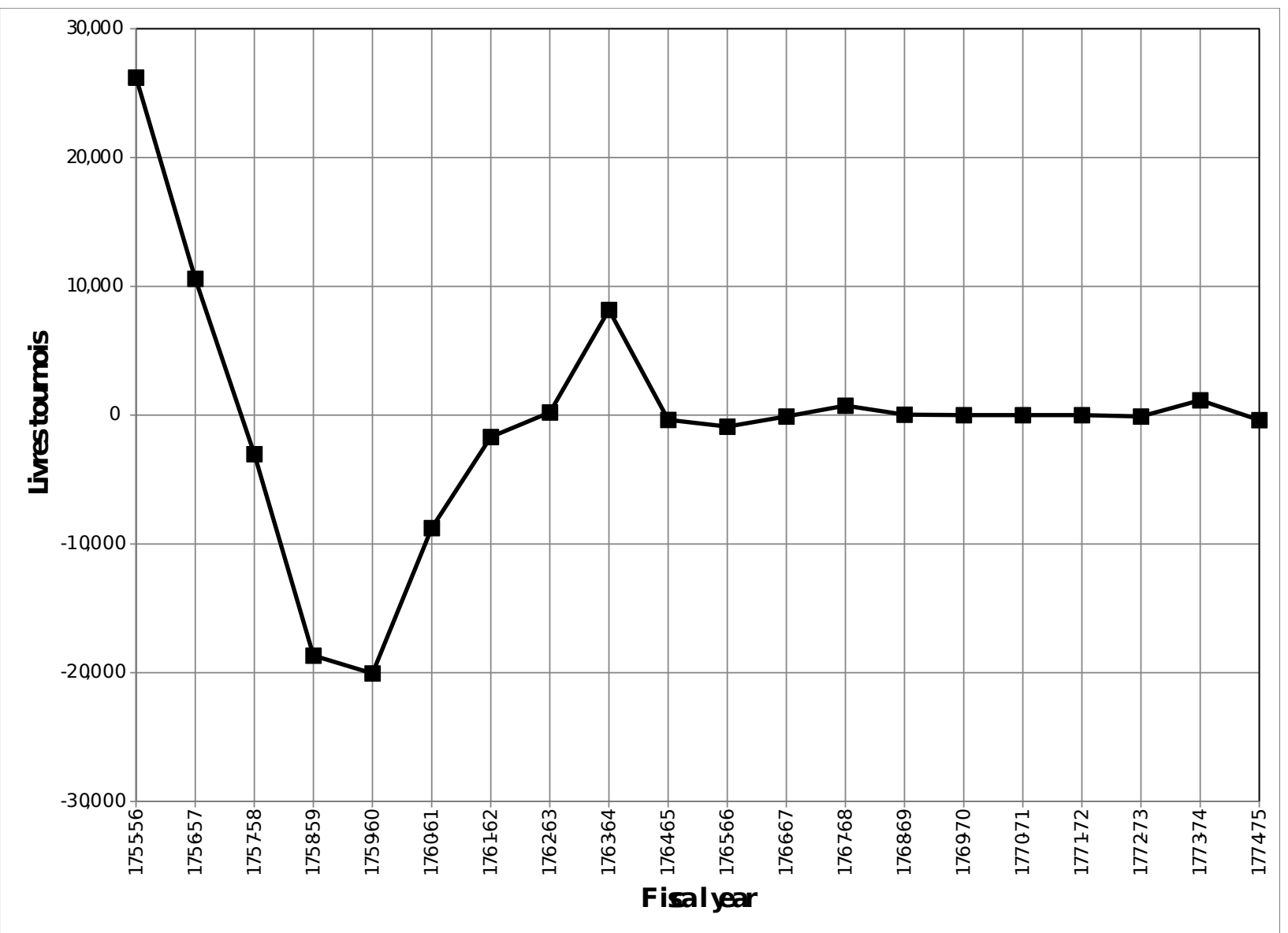

Figure 8. Annual net change to cash reserve,

$1755-56$ to $1774-75$.

There is good reason to suppose that the losses of the troupe during the Seven Years War were not peculiar to their business enterprise, but reflected a more generalized depression of the French economy that compelled Parisian consumers to reduce spending on luxury goods like theater tickets. Along with French foreign and colonial trade, the receipts of the Comédie-Française fell markedly during the war, and then recovered strongly after the Peace of Paris was signed in February 1763. [Fig. 9] A comparison of the ticket receipts of the Comédie-Française with total French exports reveals a relatively strong correlation, with $\mathrm{R}^{2}=0.26$. [Fig. 10] The Comédie-Française did not, of course, produce for the export market, but to the extent that export figures can serve as a surrogate for French GDP, they suggest that the trough we find in the

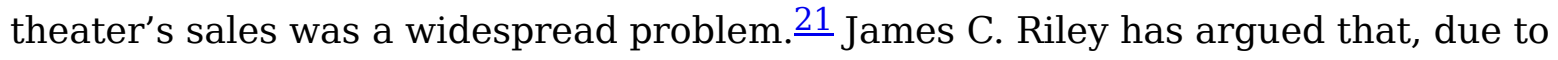
peaks of "compensatory trade" immediately before and after the war, the naval blockade did not adversely affect the French domestic economy, but there is considerable-if anecdotal-evidence to the contrary. $\underline{22}$ Data published in graphic form by Pierre Léon demonstrate a very marked decline in the production and domestic 
sales of canvas during the Seven Years War in such diverse cities as Rouen, Valenciennes and Mayenne, as well as a sharp drop in coal shipments from the Loire valley to Paris. $\underline{23}$ During the same years the sales of Parisian shopkeeper NicolasClaude Flocquet experienced a trough that mirrored that of total French exports, though he too produced only for the domestic market. The piecemeal evidence therefore suggests that economic malaise was not limited to export industries. $\underline{24}$

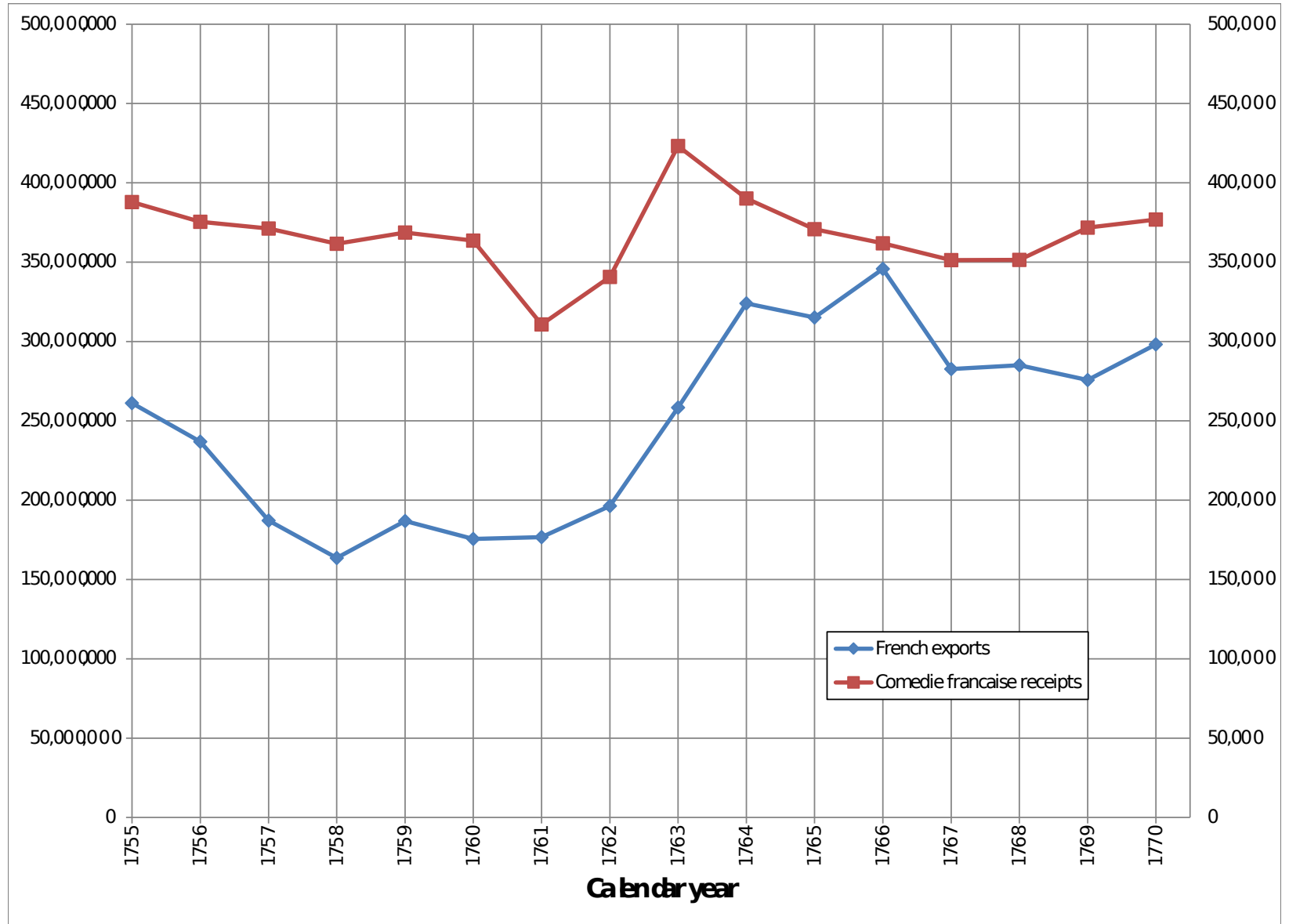

Figure 9. Comédie-Française ticket receipts and French exports, 1755 to 1770 . 


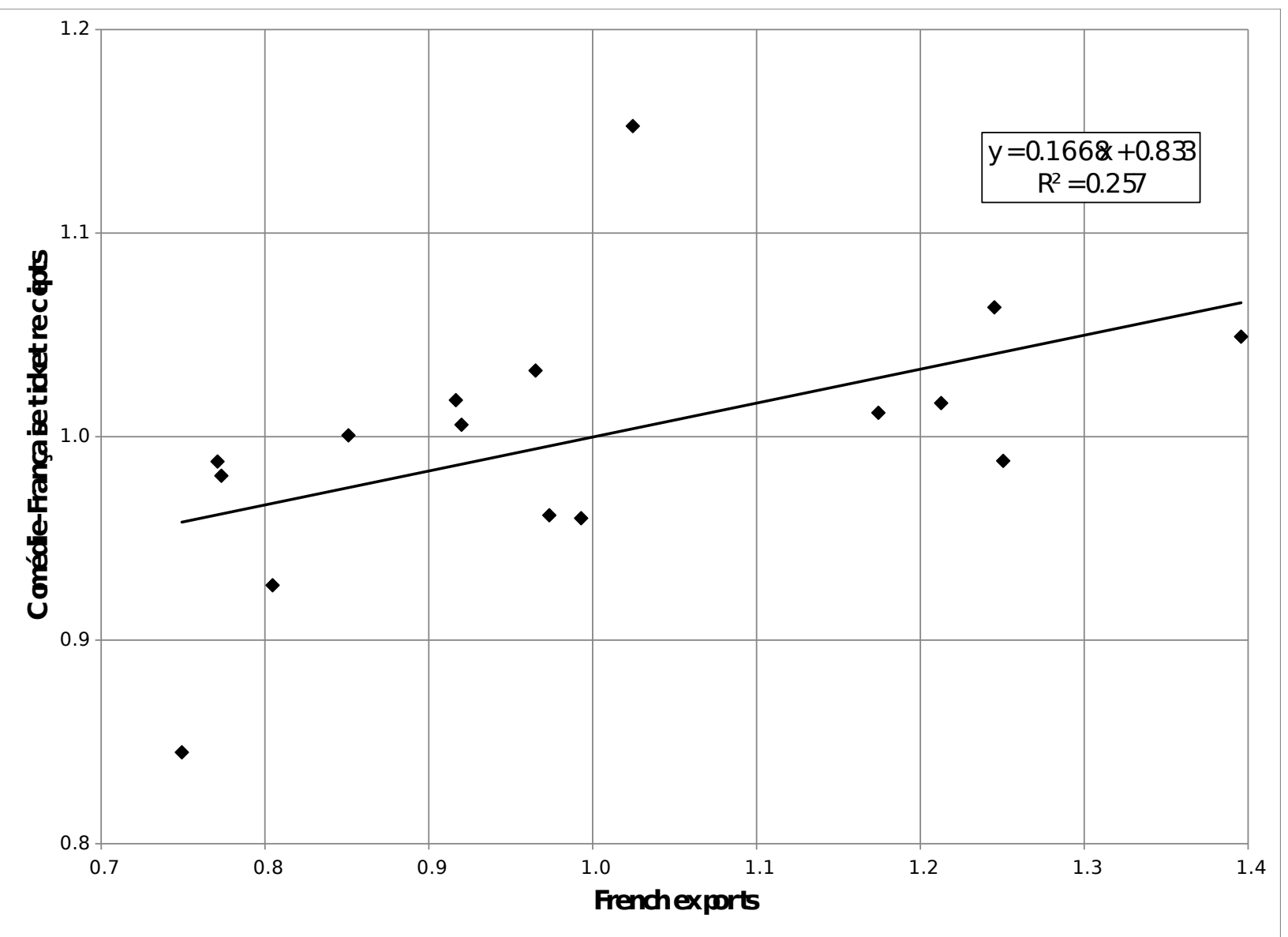

Figure 10. Regression of Comédie-Française ticket receipts on French exports, 1755 to 1770 , both series detrended by division.

The gradual financial recovery of the Comédie-Française starting about 1761 was due to a variety of factors. Most notably, the troupe succeeded in reducing both their fixed costs and their taxes. In fiscal year 1760-61, annual fixed costs were 21,614 L lower than in the previous year. The greatest cut was in the wages of dancers, slashed from 25,000 L to under 5,000 L. The registers do not reveal the thinking behind this decision, but it must have represented a shift in emphasis from spectacle to dramatic narrative. In addition to reducing several other expenses by small amounts, the troupe also seem to have persuaded the king to eliminate the fixed tax known as the Capitation, for which they had previously paid 1,104 L per year. More remarkably, their annual account shows that in 1760 the Comédie-Française was granted temporary relief on its most important taxes, which it paid each month to the HôpitalGénéral and the Hôtel-Dieu. Classified among their variable costs, these two taxes together totaled roughly twenty-two percent of all ticket receipts, but in fiscal year 1760-61 both taxes were levied only from August through March, so that the theater operated tax-free for the first four months of the season, from April through July 1760, 
producing a one-time savings of nearly 21,000 L. Starting with fiscal year 1762-63 the Comédie-Française succeeded in reducing the rate at which it paid taxes to the HôpitalGénéral and the Hôtel-Dieu, which fell below fifteen percent by the end of the war, and were finally transformed from a percentage into an essentially fixed payment of just over 62,000 L per year, regardless of growth in the theater's revenues. [Fig. 11] The troupe thus seems to have benefited from something resembling a further government bailout. $\underline{25}$

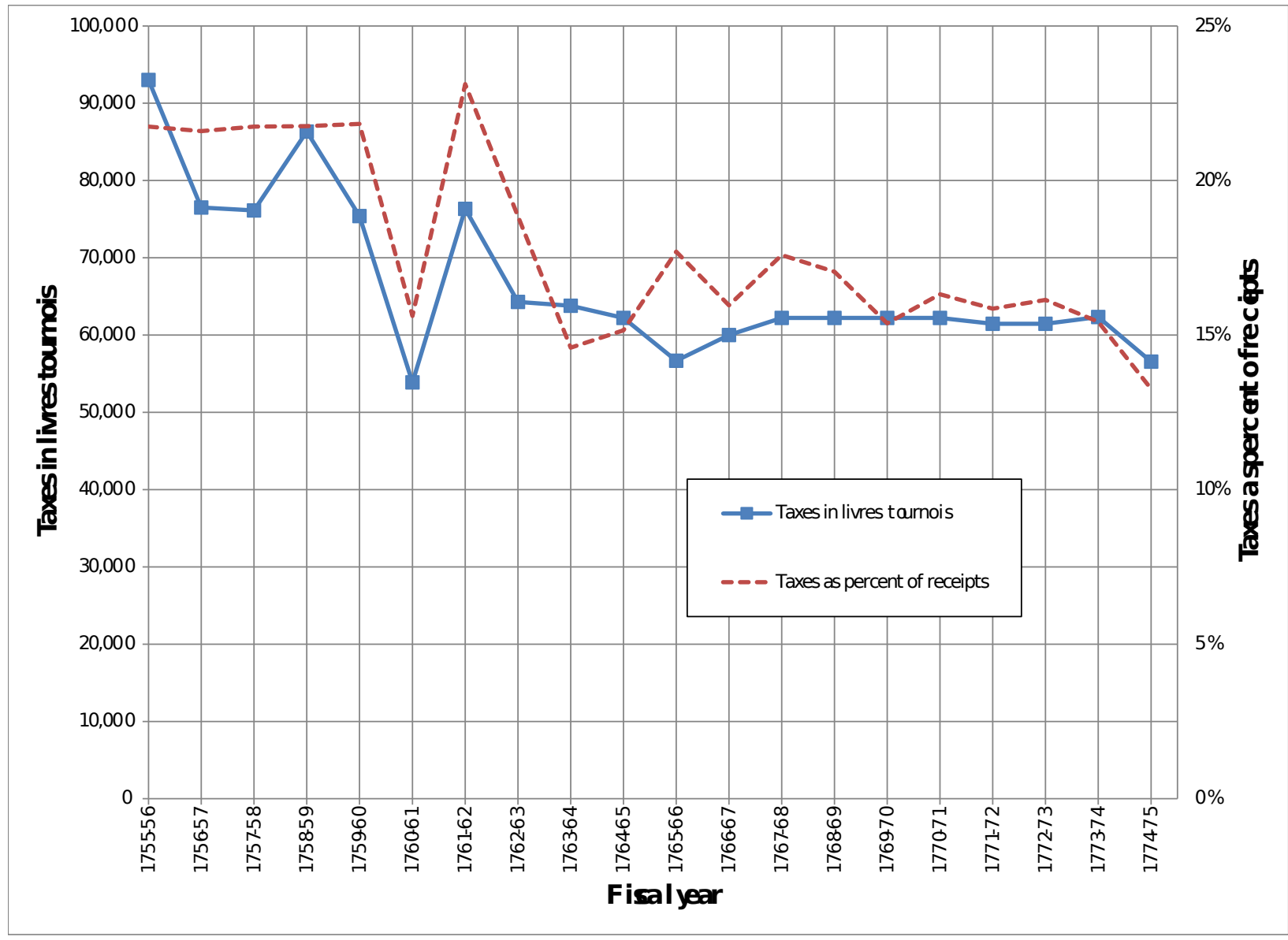

Figure 11. Annual taxes paid,
$1755-56$ to $1774-75$, 


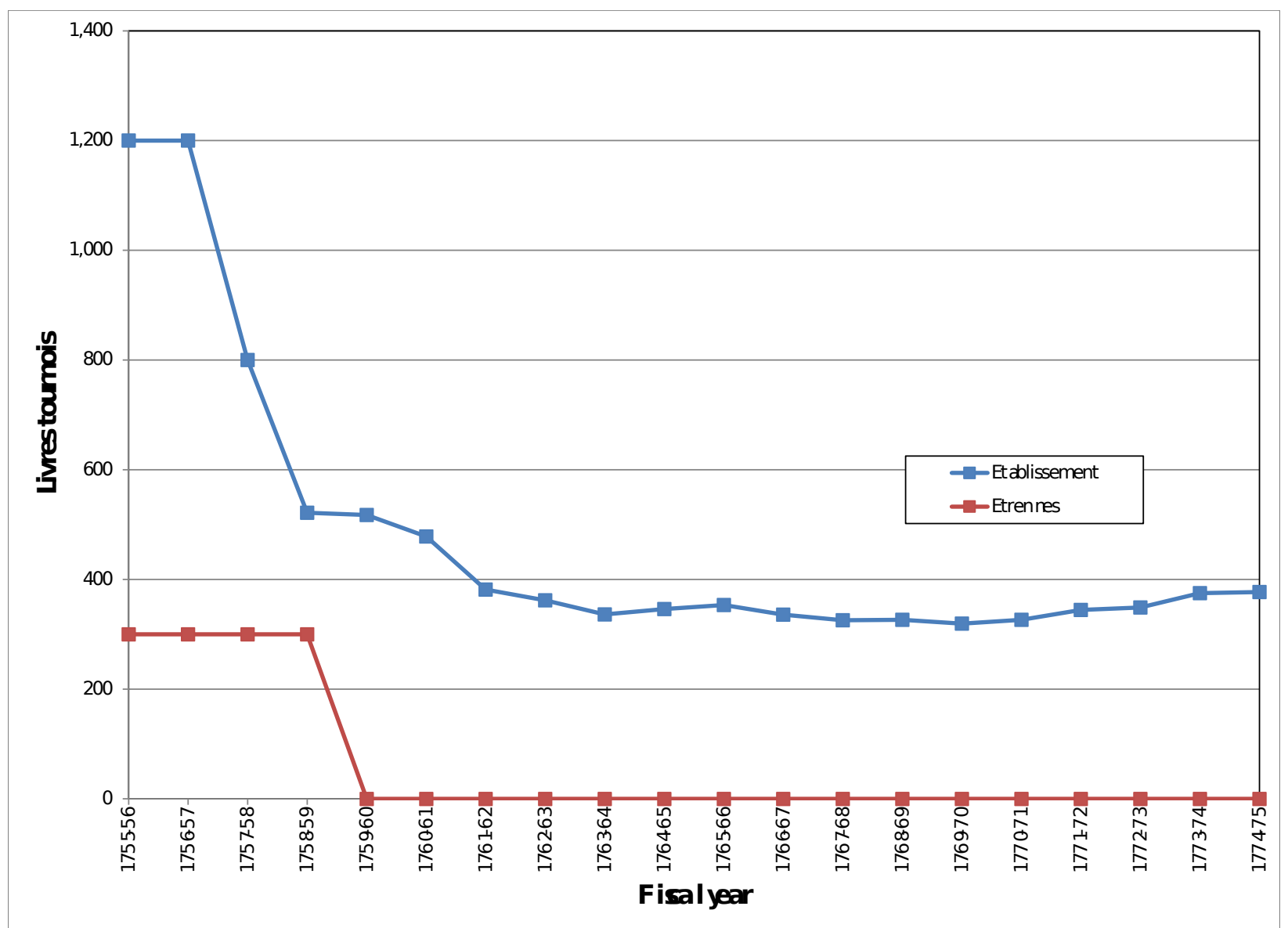

Figure 12. Compensation paid annually per share as établissement and étrennes,
$1755-56$ to $1774-75$.

To their credit, the troupe also tightened their belts by reducing their own nondividend compensation. [Fig. 12] In June 1757 the supposed interest payment that shareholders received each month, known until then as the établissement, was rechristened the intérêt du fonds d'avance, and reduced to less than half its previous level. It would continue to decline over the following years. After 1757 the theater no longer indemnified those actors and actresses who were not invited to perform for the king at Versailles. The New Year bonus was also permanently eliminated after the troupe received their final bonus at the end of 1758. The attempt was thus made to reduce other forms of compensation for actors and actresses the better to fund the dividends themselves, which starting in fiscal year 1761-62 were tied more rigorously to actual profits. In 1763-64 the cash reserve actually grew by more than 8,000 L. Thereafter net annual changes to the cash reserve stabilized at almost exactly zero, as profits and dividends became nearly identical. (see Fig. 8 above) 


\section{Strategies developed to improve ticket sales}

Beyond reducing their costs, the troupe would presumably have sought to shore up their revenues by scheduling performances with a view to improving ticket sales. The database of performances and receipts created recently by the Comédie-Française Registers Project ( $\underline{\mathrm{CFRP}}$ ) enables us to explore the strategies they adopted. The most obvious means to increase revenues was to perform more often, as in fact they did. [Fig. 13] During the first four decades of the theater's operation, the number of performance days per calendar year at their Paris location averaged over 320, but this number fell off rapidly after 1720 . The Comédie-Française averaged only 280 performance days per year in the 1730s, 275 in the 1740s, and 268 in the 1750s. This number then rose sharply after 1760, averaging 295 performance days per year in the 1760s, an increase of ten percent over the previous decade. $\underline{26}$

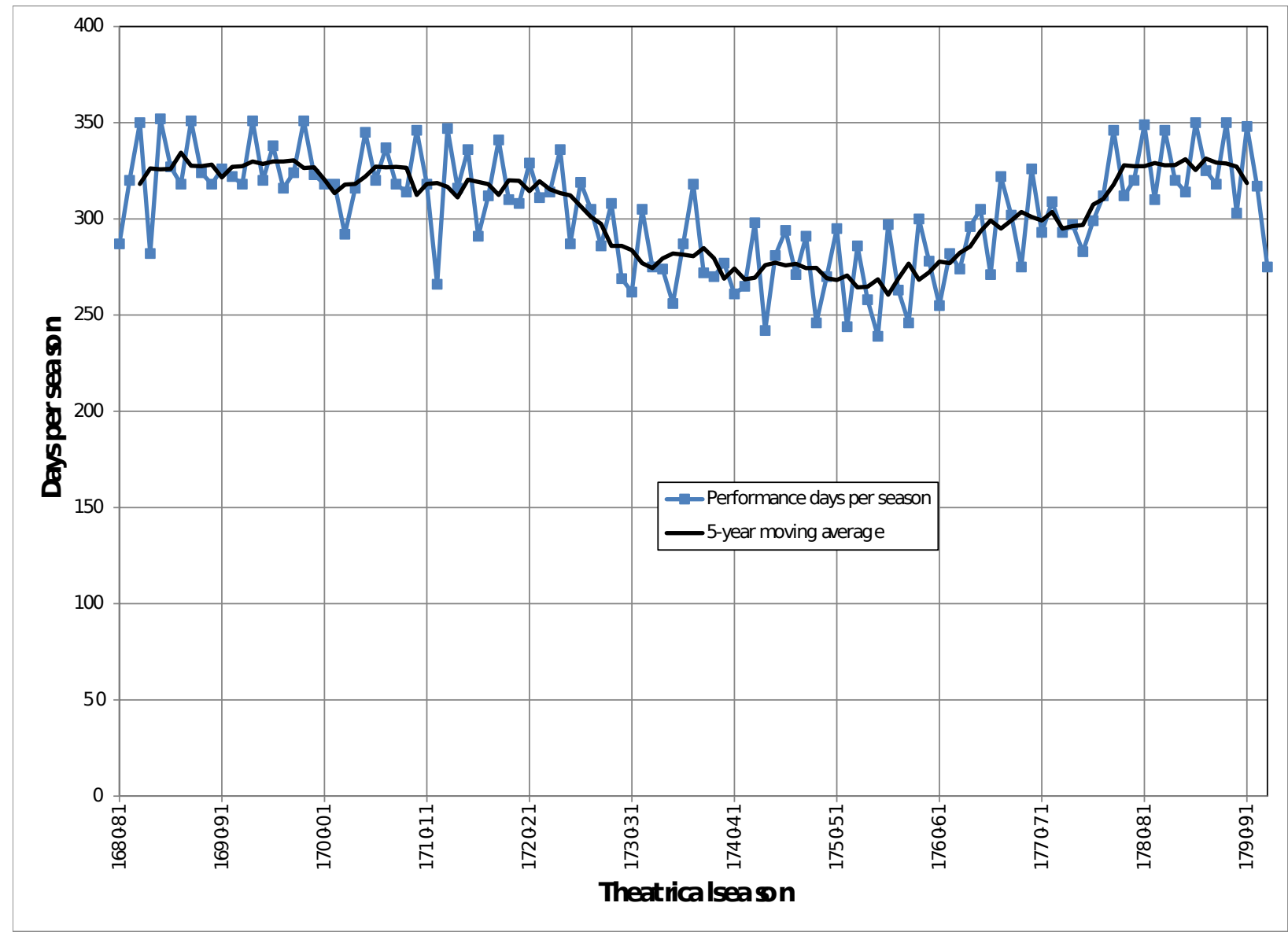
Figure 13. Number of performance days per calendar year,
1680 to 1793 .

A second strategy by which the troupe might improve ticket sales was to select a more popular genre of play for performance. The choice of genre was tied closely to, but not always determined by, the day of the week. Each day's entertainment usually included 
two plays, but while the second, much shorter play was almost invariably a comedy, the full-length play with which the performance began might be either a comedy or a tragedy-or occasionally, in fewer than ten percent of cases, some more obscure genre. The Paris Opera, the chief competitor to the Comédie-Française, opened only on Sundays, Tuesdays and Fridays, plus Thursdays during the winter months. The same days thus tended to see smaller audiences at the Comédie-Française, though Sundays could nonetheless draw a large number of spectators who had to work the rest of the week. Joseph de La Porte explained that "Les trois jours où il y a le plus de monde à la Comédie Françoise, sont le Lundi, le Mercredi \& le Samedi. C’est pour ces jours-là qu'on réserve les meilleures Pièces, ou les Pièces nouvelles.”르

The $\underline{\text { CFRP }}$ database reveals further that tragedies were usually staged on Mondays, Wednesdays and Saturdays, while comedies were done on the other four days of the week. As a result tragedies tended to bring in roughly double the ticket sales of comedies, averaging 1,794 L and $910 \mathrm{~L}$ respectively per performance over the whole period from 1750 to 1770 , but the difference seems to have been due largely to scheduling, not to the inherent popularity of the genre. Controlling for both the month and the day of the week, comedies frequently averaged greater revenue than tragedies under similar conditions of scheduling. The schedule, moreover, was flexible, and the overall proportion of comedies to tragedies in the theatrical season varied considerably over time. [Fig. 14] Having favored comedies over tragedies in the earlier decades of the eighteenth century, in the 1740s the Comédie-Française began to move toward more of a balance between the two genres, until by the early 1750s their numbers were nearly equal. Starting in the late 1750s, however, this pattern reversed sharply as the troupe scheduled fewer and fewer tragedies, and more and more comedies, which thus encroached increasingly on the high-audience days of the week. Admittedly the decision may have been driven as much by artistic as by economic considerations. While the subject is worthy of further study, however, this shift in the troupe's sales strategy starting at the height of the Seven Years War suggests that comedy may have become more popular than tragedy in a time of economic depression, as spectators sought an escape from their problems. 


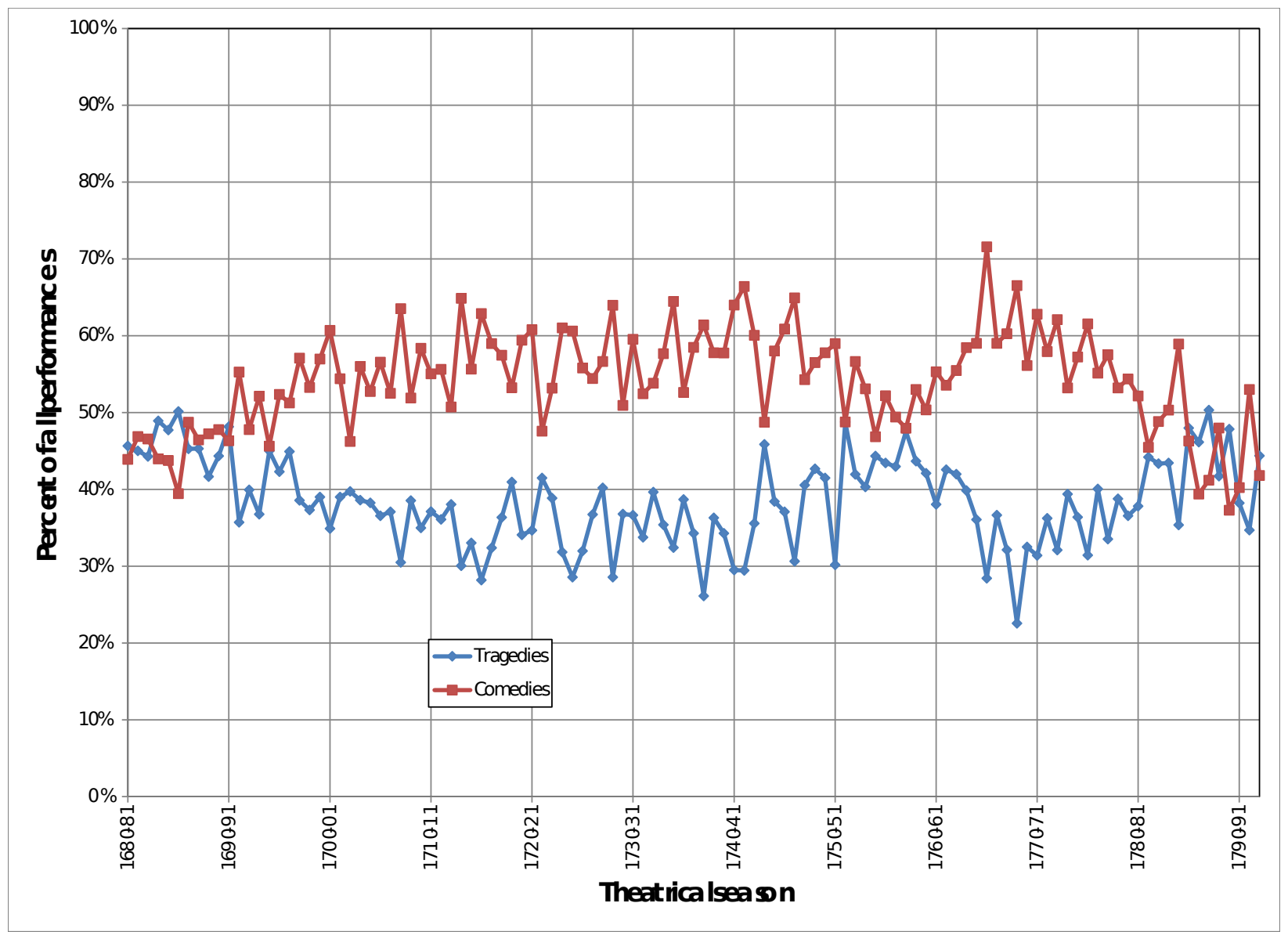

Figure 14. Comedies and tragedies as percent of all plays performed (1st play of the day), 


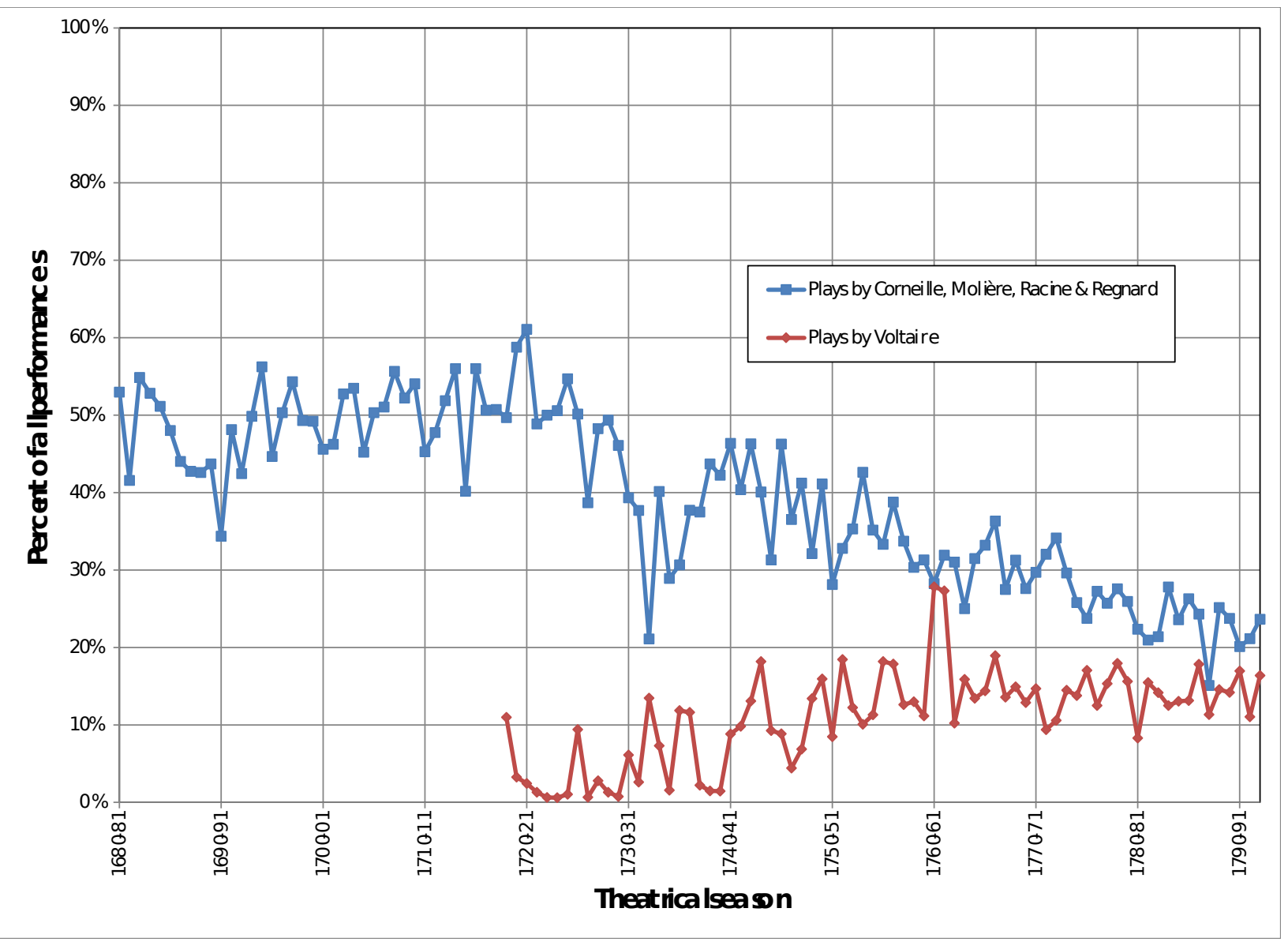

Figure 15. Plays by classic playwrights and by Voltaire as percent of all plays performed (1st play of the day), 1680-81 to 1792-93.

Another possible strategy might have been to fall back on the reliable classics of seventeenth-century drama, which, in addition to their perennial popularity, also had the advantage that they could be performed without paying royalties to the authors. Here our results are negative, however. [Fig. 15] By far the most popular classic playwrights at the Comédie-Française in the eighteenth century were Pierre Corneille, Molière, Jean Racine and Jean-François Regnard, but the frequency with which their plays were performed fell off steadily over the eighteenth century, and the period of the Seven Years War did nothing to reverse this trend. Rather, at the height of their war-time crisis, the troupe turned to Voltaire. [Fig. 16] During the consecutive theatrical seasons 1760-61 and 1761-62 (again limiting our analysis to the first play performed each day), Voltaire's plays were performed on 148 days, accounting for twenty-eight percent of all performances at the Comédie-Française, far more than in any season before or after. His plays sold so well, moreover, that they generated forty percent of the theater's revenues during the same two years, or nearly 268,000 L. It is 
not an exaggeration to say that Voltaire helped return the Comédie-Française to financial stability.

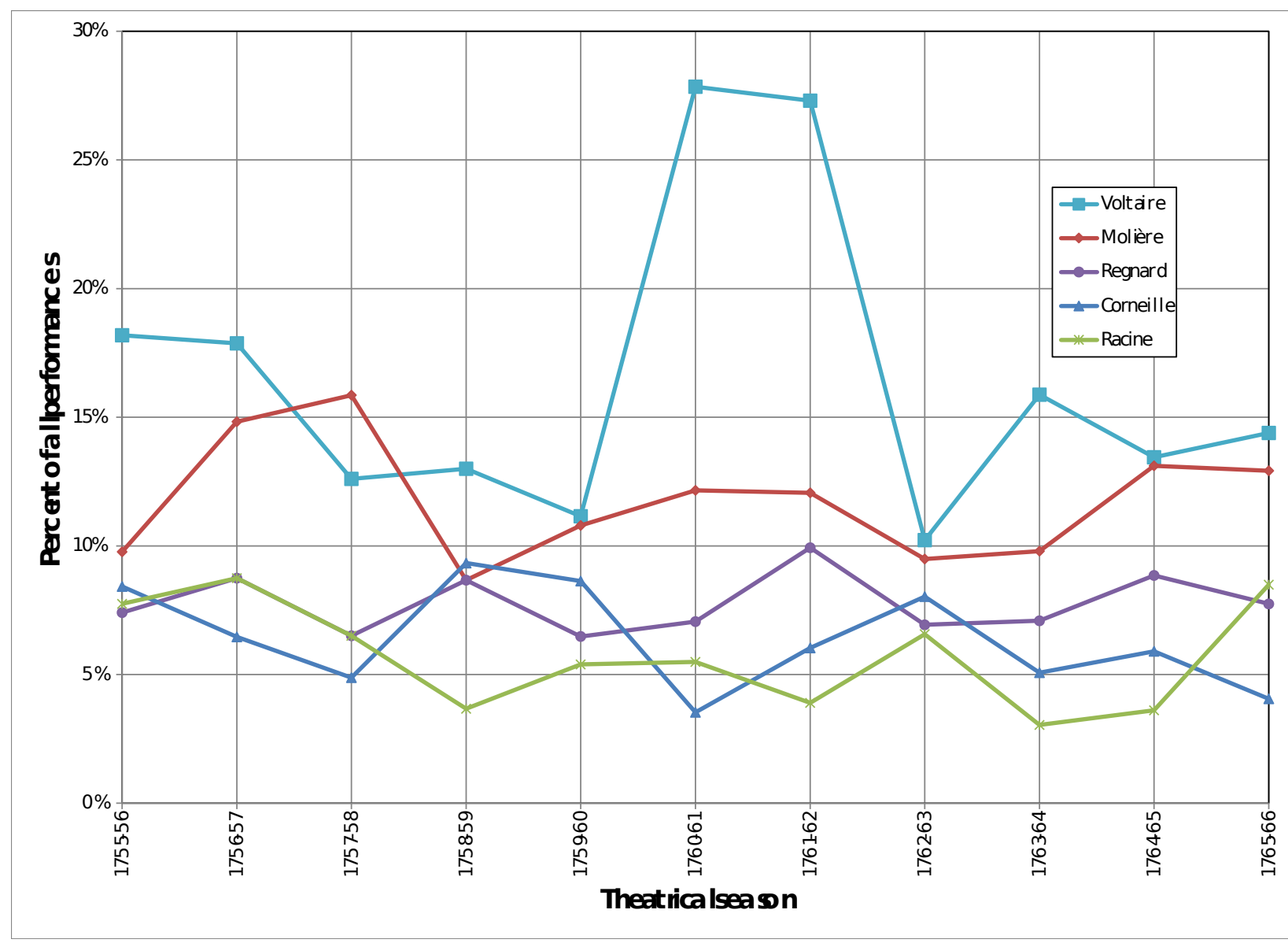

Figure 16. Plays by Voltaire, Molière, Regnard, P. Corneille and Racine as percent of all plays performed (1st play of the day), 1755-56 to $1765-66$.

By a stroke of luck, the four-month period during which the Comédie-Française operated tax-free in 1760 coincided with the debut of one of the most popular plays of its whole history, Charles Palissot de Montenoy's Les Philosophes, which it performed to packed audiences during the whole month of May. For the Comédie-Française, May was usually a sleepy month of performances before small audiences, but in May 1760 the theater grossed 41,432 L, which was more than any previous month of May since the inflationary Mississippi Bubble of 1720. On May 2, Palissot's much-anticipated play opened to an audience of nearly two thousand spectators and raked in $4,378 \mathrm{~L}$ in a single day. Over the course of the month it was performed thirteen times as the first play of the day, and once as the second play of the day, with receipts of 33,434 L, or eighty percent of the month's total. 
The box-office success of Les Philosophes, however, came at the cost of alienating many of the theater's supporters in the Parisian literary world. Bordering on libel, Palissot's play openly caricatured a number of leading intellectuals of the French Enlightenment, including Denis Diderot, Jean-Jacques Rousseau, Charles Pinot Duclos, Marie-Thérèse Rodet Geoffrin and Claude-Adrien Helvétius. Palissot portrayed the Encyclopedists as besotted, immoral, irreligious, and-at the height of the France's war against Britain-unpatriotically anglophile. Audiences reveled in the thinly disguised namedropping and the shaming of prominent public figures. The antiphilosophe journalist Elie-Catherine Fréron gave the play a glowing review in his periodical L'Année littéraire, but Diderot and his partisans were furious, and persuaded the Comédie-Française to stop performing it after the end of the May. Given their current financial straits, however, the troupe would need a new hit to replace Les Philosophes.

Though Palissot was an admirer of Voltaire, and had carefully spared him from criticism, Voltaire rallied that spring to Diderot's defense by reworking his manuscript play Le Café, ou l'Ecossaise into a counter-attack on Fréron who, under the name "Frélon" ("wasp"), became the transparent villain of the piece. Opening on July 26, 1760-thus still within the tax-free window-L'Ecossaise brought in ticket receipts of 3,760 L on its first day and a total of 45,164 L by the end of the season. In L'Année littéraire Fréron grudgingly depicted the opening performance as a battle for the parterre in which Diderot's forces had triumphed over the "people of good taste." In September 1760 Voltaire debuted his even more successful Tancrède, a tragedy that grossed 71,508 L over the following eighteen months, and whose positive portrayal of medieval Norman knights may also have helped repair the philosophes' reputation for

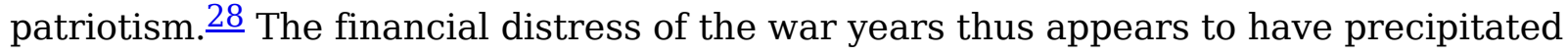
a process by which the theater become more sensitive to popular demand, and increasingly exploited notorious rivalries between public figures to improve ticket sales, a strategy that seems to have persisted beyond the war. In February and March 1765, a patriotic new tragedy by Pierre-Laurent de Belloy, Le Siège de Calais, resulted in a similar infusion of funds, with ticket sales totaling 62,707 L over just eighteen performances. Logan J. Connors has pointed out that, like Palissot's play, Le Siège de Calais was widely perceived as an attack on the French philosophes for their internationalism and consequent lack of patriotism. $\underline{29}$ 


\section{Conclusion}

The registers of the Comédie-Française offer an unusual opportunity to study the experience of a Parisian business during the economic distress of the Seven Years War. Due both to the remarkable survival of its accounts and administrative archives, and to the highly democratic structure of its administration, by which all significant business decisions were debated and decided in the weekly business meetings of the troupe, we can follow in detail the decline in the theater's revenues and profits at the height of the war, and the steps taken by the troupe to restore solvency. Initially the troupe renegotiated debts and drew down their cash reserve, even as they continued to fund their own dividends at a level that, though lower than what they were used to, was still significantly greater than their actual profits. Gradually, however, they found ways to cut costs, both through internal reforms and by securing a reduction to their tax rate. In the short run at least, the troupe regained financial stability less by enhancing their revenues than by reducing their expenses.

Nevertheless, in an attempt to improve revenues the troupe also modified their performance schedule, increasing by ten percent the number of days they performed in Paris per season, performing more comedies than tragedies, and searching for new plays that might bring in larger audiences. At this juncture the Comédie-Française turned increasingly to public scandal, transforming conflicts between prominent living individuals into the stuff of public spectacle. As Lauren R. Clay has commented, "The royal actors encouraged such rivalries because they drove sales." $\underline{30}$ Robert Darnton has pointed to the libelle as a distinctive genre of subversive literature that achieved extraordinary popularity in this period, with ultimately deleterious effects for French political culture. $\frac{31}{\text { In }} 1760$ Palissot's Les Philosophes and Voltaire's L'Ecossaise brought the libelle genre to the stage.

Thanks primarily to the favor of Étienne-François, duc de Choiseul, then minister of foreign affairs and a patron of the anti-philosophe camp, Palissot was able to publish his play legally with Parisian printer Duchesne. $\underline{32}$ Voltaire’s comedy, however, was clearly unsuitable for "approbation and privilege of the king." Apparently printed in Geneva by the Cramer brothers, L'Ecossaise appeared over the following four years in a large number of editions listing fanciful places of publication-London, The Hague, Amsterdam and Avignon-and with title pages falsely claiming that it was the latest piece by the brother of David Hume, now translated into French by one Jérôme Carré of Montauban. Though too hot for the French royal censors, L'Ecossaise remained a favorite at the Comédie-Française through the end of the old regime, with 127 
performances by 1788. Libelle thus achieved a level of toleration on the stage that it did not enjoy in print.

\section{Annex}

This MS Excel workbook accompanies the the article "Financial difficulties and business strategies at the Comédie-Française during the Seven Years War, " by Thomas M. Luckett, and provides researchers with access to the dataset of expenses of the Comédie française developed for that article, covering primarily the period from April 1755 to March 1761.

\section{Footnotes}

1. "We were poor, and unable to wait for what we were owed. The semainiers [rotating production managers] went every week to see M. de Boulogne [sic], who was then controller-general of finances, to beg him for payment of the king's pension, but obtained nothing.... The minister noticed me, dismissed the crowd who surrounded him, and approached to ask me what brought me there. I answered: 'The despair, milord, to which we are reduced by our needs and your refusals.'” Clairon [Claire-Josèphe-Hippolyte Léris de La Tude], Mémoires d'Hyppolite Clairon, et réflexions sur l'art dramatique; publiés par elle-même (Paris: Buisson, an VII [179899]), 192-193; Pierre-David Lemazurier, Galerie historique des acteurs du théâtre français, depuis 1600 jusqu'à nos jours, 2 vols. (Paris: Chaumerot, 1810), 2:75-119; Françoise Mosser, Les Intendants des finances au XVIII siècle: Les Lefèvre d'Ormesson et le "Département des impositions" (1715-1777) (Geneva: Droz, 1978), 295-296. Clairon's anecdote concludes that she succeeded in persuading Boullongne to pay the theater's royal pension in arrears. $\_$

2. I am grateful to Agathe Sanjuan and Jeffrey S. Ravel for their guidance in the development of this research, and to the participants in a workshop convened at the Massachusetts Institute of Technology on September 23, 2016, including especially Derek Miller and François Velde, for their comments and suggestions. $\subseteq$

3. The fiscal year of the Comédie-Française ran from 1 Apr. to 31 Mar., and thus differed somewhat from the variable dates of the theatrical season, which began one 
week after Easter and ended two weeks before Easter, allowing the troupe a threeweek annual vacation. $\subseteq$

4. From Apr. 1755 to Nov. 1757, the accountants simply appended the monthly accounts of expenses to the monthly accounts of receipts in the receipts registers. Bibliothèque de la Comédie française (BCF): R118-R120. From Nov. 1757 through Mar. 1760 they added them instead at the end of each month in separate expense registers (with slightly different versions of that for the single month of Nov. 1757 thus surviving in both sets of registers). BCF: R120¹-R1203, R120d. All these registers are available online at www.cfregisters.org/en/registers.

5. Covering fiscal years 1759-60 to 1792-93, the annual expense accounts have been digitized and are available in that form in the reading room of the BCF, but at present have not yet been placed online. BCF: R122 ${ }^{1}-\mathrm{R} 122^{34}$. Summaries of most of these annual accounts have been published by Claude Alasseur, La Comédiefrançaise au XVIII siècle: Étude économique (Paris: Mouton, 1967), 182-192. Alasseur's publication does not include the annual accounts for fiscal years 1759-60, 1760-61 and 1775-76. Admittedly the manuscript accounts for 1759-60 and 1775-76 are highly problematic and apparently incomplete, and the former is also redundant with the more complete monthly accounts. $\subseteq$

6. Arrests du Conseil d'Etat du roi, lettres patentes, acte de société et réglements de messieurs les premiers gentilshommes de la Chambre de roi, concernant les comédiens français (Paris: Ballard, 1761). There are at least two previous manuscript copies of the council decree: Minutier central des Archives nationales: MC/RS/750 (9 June 1758) [originally MC/ET/XLIV/1011]; BCF: R5222. The council decree is also reprinted in Nicolas-Toussaint Des Essarts, Les Trois théâtres de Paris, ou Abrégé historique de l'établissement de la Comédie française, de la Comédie italienne et de l'Opéra, avec un précis des lois, arrêts, règlements et usages qui concernent chacun de ces spectacles (Paris: Lacombe, 1777), 58-112; Charles de Fieux, Chevalier de Mouhy, Abrégé de l'histoire du théâtre françois, depuis son origine jusqu'au premier juin de l'année 1780, 3 vols. (Paris: Jorry, 1780), 3:47-59. By typographical error Des Essarts gives the date of the council decree as 17 June 1758 (58), but he also gives the correct date elsewhere (82, 295). Helpful summaries of the council decree are provided by Alasseur, La Comédie-française au XVIII siècle, 41-42; and Gregory S. Brown, A Field of Honor: Writers, Court Culture, and Public Theater in French Literary Life (New York: Columbia University Press, 2002), 76-81. 
7. Lauren R. Clay, Stagestruck: The Business of Theater in Eighteenth-Century France and its Colonies (Ithaca, NY: Cornell University Press, 2013), 99-102; Alasseur, La Comédie-française au XVIII e siècle, 39-40, 83; Des Essarts, Les Trois théâtres de Paris, 59-60, 83-84. The official French currency unit, the livre tournois ( $\square$ ), was divided into 20 sous (s), or 240 deniers (d). For the late 1750 s the sources inconsistently site the total cost per share as either $13,130 \square 15$ s $5 d$ or just $13,130 \square$ $15 \mathrm{~s}$, but the arithmetic makes it clear that the higher figure is correct. The fiction that the payment of $4,400 \square$ was not part of the share price had apparently been invented to reduce the king's liability for reimbursement should the theater ever dissolve. $\leftrightarrows$

8. Clay, Stagestruck, 100; Des Essarts, Les Trois théâtres de Paris, 159, 165, 170. For a detailed description of the internal administration of the Comédie française dated 30 Nov. 1757, see BCF: R5222, fol. 19r-27r. On the role of the semainier, see also Lerasle, Encyclopédie Méthodique: Jurisprudence, 10 vols. (Paris: Panckoucke, 1782-91), 10:757. Though royal officers known as the "intendants des Menus plaisirs" were responsible for the administration of the theater, Brown indicates that they did not become actively involved in its management until the 1770 s. Brown, $A$ Field of Honor, glossary. $\_$

9. François-Henri-Joseph Castil-Blaze, L'Académie impériale de musique: Histoire littéraire, musicale, choregraphique, pittoresque, morale, critique, facétieuse, politique et galante de ce théâtre de 1645 à 1855, 2 vols. (Paris: Castil-Blaze, 1855), 1:94-95.

10. Alasseur, La Comédie-française au XVIII siècle, 9, 115-122; BCF: R120, R1201․ 11. Here and in the following paragraphs, for the manuscript sources for the expenses and dividends of the Comédie française for fiscal years 1755-56 to 175960 , see note 3 . The estimate in figure 1 of the amount received by actors and actresses as feux for visits to Versailles may be somewhat too low since the information provided on these visits for fiscal years 1758-59 and 1759-60 is very cursory and perhaps incomplete. There is also some indication in the registers that the troupe may occasionally have performed for the king at Fontainebleau in 1755 and 1757, but those visits have not been included in this analysis. $€$ 12. Alasseur, La Comédie-française au XVIII ${ }^{e}$ siècle, 151-154. For fiscal years 175556, 1758-59 and 1760-61, I have corrected or supplemented Alasseur's figures for total dividends on the basis of BCF: R118, R120², R120d, R122². 
13. "The infamy attaching to my profession." Clairon to François-Charles Huerne de La Mothe, Paris, 5 Sept. 1760, in Huerne de La Mothe, Memoire a consulter, sur la question de l'excommunication; que l'on prétend encourue par le seul fait d'acteurs de la Comédie françoise (Paris, 1761), xv. $\Perp$

14. Adam Smith, An Inquiry into the Nature and Causes of the Wealth of Nations, 2 vols., ed. Roy H. Campbell and Andrew S. Skinner (Oxford: Oxford University Press, 1976), 1:124; Paul Friedland, Political Actors: Representative Bodies and Theatricality in the Age of the French Revolution (Ithaca: Cornell University Press, 2002), 17-20; Joy Palacios, “Actors, Christian Burial, and Space in Early Modern Paris," Past \& Present, no. 232 (August 2016): 127-163; Michael Sanderson, "Adam Smith, Sir Herbert Tree and the Wages of Actors 1890-1914," Business History 27, no. 2 (July 1985): 197-206; Adresse et projet de statuts et reglemens pour l'Académie Centrale de Peinture, Sculpture, Gravure et Architecture (Paris: Valade, 1790), 76.

15. On François Baron, see Lemazurier, Galerie historique, 1:121-122. The caisse de M. Baron should not be confused with a separate reserve called the séquestre, an escrow account managed by the official notary of the Comédie-Française, Nicolas de Savigny. At any given time the number of shares actually owned by members of the troupe was typically somewhat less than twenty-three, but the "vacant" (unowned) shares or partial shares continued to earn dividends that were paid into the séquestre. Funds could be spent out of the séquestre only by order of the king, and then only to reimburse the theater's debts. Des Essarts, Les Trois théâtres de Paris, $109,121,126,130 . \unlhd$

16. Mouhy, Abrégé de l'histoire du théâtre françois, 3:356; Jules Bonnassies, La Comédie-Française: Histoire administrative (1658-1757) (Paris: Didier, 1874), 229230.

17. "That the circumstances of the present time, joined with the excessive and extraordinary expenditures that it has been necessary to make since the beginning of the season, do not at present permit the reimbursement of the stated sum." BCF: R52 ${ }^{22}$, fol. 128v, 136v, 144r. On Dangeville, Lekain and Préville, see Lemazurier, Galerie historique, 1:209-211, 333-369, 477-501. 18. BCF: R5222, fol. 186r-187r, 194r-194v; R124', fol. 39v-40r; R124a, fol. 11r-11v; Lemazurier, Galerie historique, 2:49-55, 244-246, 274-278. Lemazurier mistakenly cites Lavoy's given name as "Anne-Pauline." It appears from the annual expense 
account that, after their retirement from the theater, Grandval, Lavoy, Lamotte and Brillant ceased to receive dividends on their shares, which were paid instead into the séquestre, so they had good reason to demand the reimbursement of the purchase cost. BCF: R122 ${ }^{1} . \pm$

19. Annual expenses and dividends presented here for fiscal years 1755-66 to 175960 are summed from monthly figures presented above, and receipts are from BCF: R118-122 and the CFregisters.org database. Expenses, dividends and receipts for fiscal year 1760-61 are from BCF: R122². Those for fiscal years 1761-62 to 1774-75 are from Alasseur, La Comédie-française au XVIII siècle, 182-187, who derives them from BCF: $122^{3}-122^{16} \cdot \subseteq$

20. BCF: R1203, fol. 3r. $\leftrightharpoons$

21. For French exports, see Ruggiero Romano, "Documenti e prime considerazioni intorno alla 'Balance du commerce' della Francia dal 1716 al 1780," in Studi in onore di Armando Sapori, 2 vols., 2:1265-1300 (Milan: Istituto editoriale cisalpino, 1957). 22. James C. Riley, The Seven Years War and the Old Regime in France: The Economic and Financial Toll (Princeton, NJ: Princeton University Press, 1986), 112121.

23. Pierre Léon, "L'Elan industriel et commercial," in Fernand Braudel and Ernest Labrousse, eds., Histoire économique et sociale de la France, 4 vols. (Paris: PUF, 1970-1982), 2:511, 518, 522.

24. Thomas M. Luckett, "The Sales and Business Strategies of a Parisian Artisan, 1754-1764: The Letters and Accounts of N.-C. Flocquet," Proceedings of the Western Society for French History 36 (2008): 93-108. $\triangleq$

25. Alasseur, La Comédie-française au XVIII ${ }^{e}$ siècle, 96, 180-183. Taxes for fiscal years 1755-56 to 1759-60 are derived from the monthly expense accounts cited above, note 3. Those for fiscal year 1760-61 are from BCF: R122². I have not included here several smaller payments that appear in the expense accounts during the late 1750s and that, depending on one's definition, might also be considered taxes: "Bureau des pauvres Saint-Sulpice" (about 10 1 per year), "Redevance à l'Abbaye Saint-Germain-des-Prés" (250 per year), "Rachat et imposition annuelle des Boues et lanternes" (417\ 1d in 1760-61), and "Aumônes" (190־ 8d in 1760-61). $\Xi$ 
26. The analysis in this and the following paragraphs is based on data derived from the CFRP database using the $\underline{\text { Cross-Tab Browser, supplemented by the Faceted }}$ Browser. $\doteq$

27. "The three days with the most people at the Comédie française are Mondays, Wednesdays and Saturdays. For those days they reserve the best plays, or the new plays." Joseph de La Porte, “Jours de spectacles," Les Spectacles de Paris, ou Suite du Calendrier historique et chronologique des théatres 18 (1769): front matter. $\boxminus$

28. Charles Palissot de Montenoy, Les Philosophes (Paris: Duchesne, 1760); Voltaire, Le Café, ou l'Ecossaise ("Londres": 1760); Élie-Catherine Fréron, "Les Philosophes," L'Année littéraire 1760, t. 4:217-240; Fréron, “Relation d'une grande Bataille," L'Année littéraire 1760, t. 5:209-216; Voltaire, Tancrède (Paris: Prault, 1760). There is extensive modern scholarship on the circumstances and literary querelles surrounding the performances of Palissot's Les Philosophes and Voltaire's Le Café, ou l'Ecossaise in 1760. For an excellent recent study, which includes a detailed bibliography, see Logan J. Connors, Dramatic Battles in Eighteenth-Century France: Philosophes, Anti-Philosophes and Polemical Theatre (Oxford: Voltaire Foudation, 2012), in SVEC 2012, no. 7. $匚$

29. Connors, Dramatic Battles in Eighteenth-Century France, 222; Theodore Besterman, Voltaire (New York: Harcourt, Brace \& World, 1969), 403. See also John Stanton Henderson, Voltaire's Tancrède (Geneva: Institut et Musée Voltaire, 1968), in Studies on Voltaire and the Eighteenth Century, no. 61.

30. Lauren R. Clay, “The Strange Career of Voltaire, Bestselling Playwright of Eighteenth-Century_France,". in this volume. For a similar interpretation of Palissot's popularity, see also Pierre Frantz, “Le Moment Voltaire,” in this volume. $\_$

31. Robert Darnton, The Literary Underground of the Old Regime (Cambridge, Mass.: Harvard University Press, 1982), 167-208; The Forbidden Best-Sellers of PreRevolutionary France (New York: W. W. Norton, 1995), 137, 198-216.

32. Connors, Dramatic Battles in Eighteenth-Century France, 57, 124-125. 